DOI: 10.12731/2658-6649-2020-12-1-60-63

UDC 633.88

\title{
THE BIOLOGICAL ACTIVITY \\ OF COLLOIDAL COPPER PARTICLES OBTAINED BY "GREEN SYNTHESIS" BASED ON THE EXTRACT OF THE ALCHEMILLA VULGARIS
}

Kozlova V.N., Nikishina M.B., Ivanova E.V., Atroshchenko Yu.M.

The effect of colloidal copper particles on the germination energy and biometric parameters of wheat seedlings was studied.

Keywords: colloidal copper particles; growth regulators; germination energy.

\section{БИОЛОГИЧЕСКАЯ АКТИВНОСТЬ КОЛЛОИДНЫХ ЧАСТИЦ МЕДИ, ПОЛУЧЕННЫХ ПУТЕМ «ЗЕЛЕНОГО СИНТЕЗА» НА ОСНОВЕ ЭКСТРАКТА МАНЖЕТКИ ОБЫКНОВЕННОЙ}

Козлова В.Н., Никишина М.Б., Иванова Е.В., Атрощенко Ю.М.

Изучено влияние коллоидных частии меди на энергию прорастания $и$ биометрические показатели проростков пшеницы.

Ключевые слова: коллоидные частицы меди; регуляторы роста; энергия прорастания.

The materials presented in the article describe the effect of colloidal copper particles synthesized on the basis of the Alchemilla vulgaris extract on the germination energy and biometric parameters of wheat seedlings. It is known that colloidal copper particles exhibit pronounced biological activity, including bacteriostatic and bactericidal action [1]. Copper nanoparticles were obtained by the method of "green synthesis" by reducing copper nitrate to metal. Extracts from the Alchemilla vulgaris were used as reducing agents. The recovery involves biologically active substances contained in plants, namely tannins, flavonoids, anthracene derivatives, coumarins, terpenoids, polysaccharides.

The starting aqueous plant extract was prepared in a Soxhlet extractor. The weight of a sample of plant material was $50 \mathrm{~g}$, the volume of water was $250 \mathrm{ml}$. 
Further, on the basis of the initial solution by dilution, three extracts of different degrees of dilution were obtained (table 1).

Table 1.

\section{Preparation of aqueous extracts of ordinary cuffs of varying degrees of dilution}

\begin{tabular}{|c|c|}
\hline № plant extracts & Power dilution \\
\hline 1 & Source extract \\
\hline 2 & 10 -fold dilution \\
\hline 3 & 100 -fold dilution \\
\hline
\end{tabular}

To obtain a colloidal solution, $8.5 \mathrm{ml}$ of the filtered initial extract was added dropwise to $50 \mathrm{ml}$ of a solution of copper nitrate $(\mathrm{C}=0.001 \mathrm{~mol} / \mathrm{L})$ at room temperature, with constant stirring. The color of the solution became darker after 10 minutes of reaction, which indicated the development of copper nanoparticles. To study the effect of concentration on the biological activity of colloidal copper, three solutions were prepared by dilution: the initial solution (1), dilution 10 times (2), dilution 100 times (3), and dilution 1000 times.

The effect on seed germination energy is one of the indicators of the stimulating activity of any drug. Wheat seeds were chosen as the object of study because of their optimal size, short germination time, and high stress resistance. Data on the study of germination energy are presented in table 2.

Table 2.

Wheat germination energy

\begin{tabular}{|c|c|c|c|}
\hline \multirow{2}{*}{ Seed treatment } & \multicolumn{3}{|c|}{ Germination energy, \% } \\
\cline { 2 - 4 } & 3 days after soaking & 6 days after soaking & 9 days after soaking \\
\hline Colloid № 1 & 76,7 & 93,3 & 93,3 \\
\hline Colloid № 2 & 76,7 & 76,7 & 93,3 \\
\hline Colloid № 3 & 83,3 & 83,3 & 83,3 \\
\hline $\mathrm{H}_{2} \mathrm{O}$ & 93,3 & 93,3 & 100 \\
\hline $\mathrm{Cu}\left(\mathrm{NO}_{3}\right)_{2}$ & 66,7 & 73,3 & 96,7 \\
\hline Extract № 1 & 73,3 & 73,3 & 83,3 \\
\hline Extract № 2 & 80,0 & 93,3 & 93,3 \\
\hline Extract № 3 & 73,3 & 83,3 & 93,3 \\
\hline
\end{tabular}

The data presented in table 2 show that neither the original extracts nor the synthesized colloids show a significant ability to stimulate the processes of seed germination. The highest rates of germination energy are observed in the experiment with water.

Biometric indicators recorded on the 9th day after the start of treatment allow us to evaluate the biological activity of the tested drugs in relation to the 
growth processes that occur in plants at the initial stage of development. The sizes of wheat shoots treated with different compositions are presented in table 3 .

Table 3 .

Biometry of wheat plants

\begin{tabular}{|c|c|c|c|c|c|c|c|c|}
\hline & $\begin{array}{l}\overline{0} \\
\overline{0} \\
\overline{0}\end{array}$ & $\begin{array}{l}\overline{0} \\
\overline{0} \\
\overline{0} \\
0\end{array}$ & 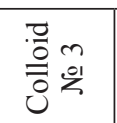 & $\mathfrak{O}^{N}$ & $\overbrace{J^{2}}^{\pi}$ & 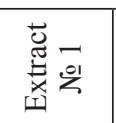 & 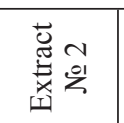 & 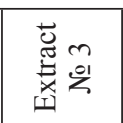 \\
\hline \begin{tabular}{|c|} 
Shoot \\
eeight, $\mathrm{cm}$
\end{tabular} & $11,3 \pm 0,9$ & $12,0 \pm 1,6$ & $15,6 \pm 1,3$ & $21,4 \pm 4,5$ & $14,2 \pm 1,3$ & $14,3 \pm 1,4$ & $14,3 \pm 1,4$ & $14,35 \pm 1,1$ \\
\hline
\end{tabular}

The data in table 3 show that the extracts of the Alchemilla vulgaris, as well as colloidal solutions of copper obtained on the basis of these extracts, inhibit the growth processes in the shoots of wheat in the early stages.

\title{
References
}

1. Gul'chenko S.I., Gusev A.A., Zakharova O.V. Vestn. Tamb. un-ta. Ser. Estestvennye i tekhnicheskie nauki. 2014. Vol. 19, no. 5, p. 1397-1399.

2. Metodicheskie rekomendatsii po opredeleniyu fungitsidnoy aktivnosti novykh soedineniy [Guidelines for determining the fungicidal activity of new compounds]. Cherkasy: NIITEKHIM, 1984. $34 \mathrm{p}$.

3. Gosudarstvennyy katalog pestitsidov i agrokhimikov, razreshennykh $k$ primeneniyu na teritorii Rossiyskoy Federatsii [The state catalog of pesticides and agrochemists approved for use on the territory of the Russian Federation], part 1. M .: Agrorus, 2018. 957 p.

\section{Список литературы}

1. Гульченко С.И., Гусев А.А., Захарова О.В. Перспективы создания антибактериальных препаратов на основе наночастиц меди // Вестн. Тамб. ун-та. Сер. Естественные и технические науки. 2014. Т. 19, вып. 5. С. 1397-1399.

2. Методические рекомендации по определению фунгицидной активности новых соединений. Черкассы: НИИТЭХИМ. 1984. 34 с.

3. Государственный каталог пестицидов и агрохимиков, разрешенных к применению на територии Российской Федерации, часть 1. М.: Агрорус, 2018. 957 с.

\author{
DATA ABOUT THE AUTHORS \\ Kozlova Valeria Nikolaevna \\ Tula State Lev Tolstoy Pedagogical University \\ 7, Mendeleevskaya Str., Tula, 300041, Russian Federation \\ valeri.kozlova5@yandex.ru
}


Nikishina Maria Borisovna, Ph.D., Associate Professor

Tula State Lev Tolstoy Pedagogical University

7, Mendeleevskaya Str., Tula, 300041, Russian Federation mama-67@mail.ru

Ivanova Evgenia Vladimirovna, Ph.D., Associate Professor

Tula State Lev Tolstoy Pedagogical University

7, Mendeleevskaya Str., Tula, 300041, Russian Federation

omela005@gmail.com

Atroshchenko Yuri Mikhailovich, Doctor of Chemical Sciences, Professor

Tula State Lev Tolstoy Pedagogical University

7, Mendeleevskaya Str., Tula, 300041, Russian Federation

reaktiv@tsput.ru

\section{ДАННЫЕ ОБ АВТОРАХ}

\section{Козлова Валерия Николаевна}

Тульский государственный педагогический университет им. Л.Н. Толстого

ул. Менделеевская, 7, Тула, 300041, Российская Федераџия valeri.kozlova5@yandex.ru

Никишина Мария Борисовна, к.Х.Н., доцент

Тульский государственный педагогический университет им. Л.Н. Толстого ул. Менделеевская, 7, Тула, 300041, Российская Федерация mama-67@mail.ru

Иванова Евгения Владимировна, к.Х.н., доцент

Тульский государственный педагогический университет им. Л.Н. Толстого ул. Менделеевская, 7, Тула, 300041, Российская Федерация omela005@gmail.com

Атрощенко Юрий Михайлович, д.Х.Н., профессор

Тульский государственный педагогический университет им. Л.Н. Толстого

ул. Менделеевская, 7, Тула, 300041, Российская Федерация reaktiv@tsput.ru 